\title{
THE IMPACT OF FISCAL POLICY TOWARD ECONOMIC PERFORMANCE AND POVERTY RATE IN INDONESIA
}

\author{
Indra Maipita \\ Mohd. Dan Jantan \\ Nor Azam Abdul Razak ${ }^{1}$
}

\begin{abstract}
The government is continuously formulating some policies in order to boast economic growth and downsize poverty rate. However, the government is facing some obstacles such as an increasingly in budget deficit which is potentially impacting to the determining of priority scale as well as the pro and contra within it. Based on that consideration, economic policy is needed to be revised and redesigned in order to meet the need of pro growth, pro job, and pro poor. Generally, this research aims to examine the impact of an expansion and contraction of fiscal policy measures on Indonesia economic performance. For the purpose of this study, the change of macro economic indicators, economic sector performance, and the change of poverty and income distribution are examined using the Computable General Equilibrium (CGE) model. In order to evaluate the disparity of income distribution, beta distribution function is used which is adopted from Decaluwe, et al. (1999). This study employs Foster, Greer, and Thorbecke (F-G-T) and Cockburn (2001) methods to evaluate poverty (poverty incidence) on each household group. The results of this study show that the impact of an increase in subsidy is more favourable than two others fiscal policy measures. Even though the policy of transfer income gives a positive impact for the upsizing of rural household income and the downsizing in poverty, but on the other hand it has negative impact on others household income which aggregately has a negative impact on the decreasing of GDP.
\end{abstract}

JEL Classification: 132, E62.

Keywords: fiscal policy, poverty, income distribution

1 Indra Maipita is a lecturer at State University of Medan (imaipita@gmail.com); Mohd. Dan Jantan is a leture at Universiti Utara Malaysia (djantan@uum.edu.my); Azam Abdul Razak is a lecturere at Universiti Utara malaysia (azam@uum.edu.my). 


\section{INTRODUCTION}

Poverty alleviation has been the objective of fundamental development that becomes an indicator to asses the effectiveness of various development programs. Based on that view, the government has been establishing some poverty alleviation programs since 1960's by using the strategy of fulfilling people's basic need as stated in the Eight-year National Development Plan (Pembangunan Nasional Berencana Delapan Tahun, Penasbede). Unfortunately, this program halted due to a political crisis in 1965. However in 1970's, the government had been reestablished poverty alleviation program through the Five-year National Development Plan (Repelita). During the Repelita V-VI, the government implemented poverty alleviation program using a distinctive strategy which was eradicating socio-economic disparity problems. For the last 40 years the government observed that there were some obstacles in implementation of various poverty alleviation programs. Consequently, the government's efforts in tackling poverty have not been achieved.

Poverty remains the biggest problem within the scope of economic development in Indonesia. The Central Bureau of Statistic (BPS) reported that there were 35 million (15.47 percent) poor people in 2008. Eventhough, this number was $6 \%$ less than those in 2007, but the 2008 figure was almost equal to those in 1990 and 2005. Poverty rate in 2009 has decreased by 1.32 percent compared to those in 2008 . The disparity in income distribution, welfare, and poverty once again attracts the attention of many parties, such as development planner, social researcher, politician, and citizen at large. These problems show that economic growth is not automatically parallel with the expansion of employement and the reduction of poverty rate. Thus, economic policy should be re-designed towards more pro growth, pro job, dan pro poor.

The government has designed some policies to promote economic growth and at the same time to eradicate poverty. However, budget deficit is the main obstacle faced by the government. And, this budget deficit keeps increasing over the years. If this condition persist, then there will be a big pressure on national budget (APBN), especially on expenditure side. The changing position of Indonesia from net oil exporter to net oil importer resulted in deficit in Indonesia's trade balance. A huge subsidy on refined fuel oil in national budget and the same time an increasing in the price of crude palm oil (CPO) have in part contributing to the burden of government in national budget. In order to reduce the budget deficit, the government has opted to undertake a fiscal policy contaction by reducing subsidy on fuel (BBM). This policy absolutely has a negative impact on poor households. Since this impact is anticipated, then at the same time the government implemented income transfer in the form of cash grant to poor households (unconditional transfer). 
The general objective of this study is to assess the impact of various government fiscal policy measures on income distribution and poverty rate in Indonesia. Specifically, this research is aimed to analyze the impact of: (1) an expansion and contraction of fiscal on Indonesia macro-economic performance, (2) an increse in tax on sectoral economic performance, (3) an increase in tax on income and poverty in Indonesia, (4) an increase in subsidy on sectoral economic performance, (5) an increase in subsidy on income and poverty in Indonesia, (6) a transfer of income on sectoral economic performance, (7) a transfer of income on income and poverty in indonesia, and (8) an expansion and contraction of fiscal on income distribution and poverty in Indonesia.

\section{THEORY}

\section{II.1. Fiscal Policy}

Fiscal policy consists of two main instruments, (1) tax policy and (2) government expenditure (Mankiw, 2003; Turnovsky, 1981), however, any policy directly affect the aggregate demand components fall in this fiscal policy. According to Sudiyono (1985) the variable instruments of fiscal policy could be in the form of tax, government transfer, subsidies, and government expenditure. Fiscal policy or budgetary has three functions: (1) allocation function, (2) distribution function, and (3) stabilization function. Allocation function is related to the provision of social good and the total utilization process of resources for the production of private goods, social goods, and the combination of selected social goods. Distribution function is related to the equity of wealth and income distribution within a society. While stabilization function is aimed to stabilize or maintain low unemployment rate, price or inflation rate, and targeted economic growth.

\section{II.2. The Effect of Keynesian's Fiscal Policy}

Keynes postulates that during an economic turmoil, monetary policy such as a decreasing interest rate is ineffective. The agregate demand could be increased rapidly by only fiscal policy measure (Romer, 2001). In the Keynes Macroeconomic model, government budget is the pivotal part in order to control the agregate demand. If the economic is below full employment level, agregate demand could be increased by increasing government expenditure and / or by decreasing the tax rate. According to Keynes, the government has a very important role to promote agregate demand towards achieving full employment level.

The core problems in most developing economies are high unemployment and inflation rates, and deficit current account or external imbalance. To overcome these problems, a high 
economic growth is required, but the expansionary policy to increase the growth rate has a drawback in terms of unbalance between high growth in demand and the existing supply capacity in the economy. This would impact the external balance which is an increse in imports and a decrese in exports, as well as an excess demand that would cause a high inflation. As a result of these situations, an economy might loose its competitiveness which eventually worsen the external imbalance. Eventhough it is achievable to increase employment level but it creates the problems of worsening current account and balance of payment (BOP).

The conflict between external and internal balance obliged an effective fiscal policy with minor negative impact. Historically, developing countries relied on fiscal expansionary policy in order to attain economic growth. The Fleming-Mundell Model of the standard ISLM model employing Keynesians approach could explain that historical phenomenon. The assumptions used in the Mundell-Fleming (MF) Model of Balance of Payment (BOP) are: (1) nominal wage and fixed price, (2) agregate demand is positively related to government expenditure (G) and foreign output (Yf), and exchange rate (e) is negatively related to domestic interest rate $(\mathrm{rd}),(3)$ money demand is a negative function of world interest rate ( $\left.\mathrm{r}^{*}\right)$ and a positive function of domestic income rate, (4) money supply is negatively influenced by deviation between exchange rate (e) and targeted exchange rate (e*), (5) trade value is determined by domestic output rate (Yd) and foreign output rate (Yf), and (6) capital account is determined by the difference between foreign and domestic interest rates (Husain and Chowdhury, 2001).

The degree of capital mobility is determined by the sensivity of interest rate differences between $r$ and $r^{*}$, which has a pivotal role in MF model.

$$
\begin{aligned}
& \mathrm{Y}=\mathrm{C}(\mathrm{Y}-\mathrm{T})+\mathrm{I}\left(\mathrm{r}^{*}\right)+\mathrm{G}(\mathrm{D})+\mathrm{NX}(\mathrm{e}) \\
& \mathrm{M} / \mathrm{P}=f\left(\mathrm{r}^{*}, \mathrm{Y}\right) \\
& \mathrm{BOP}=f\left(\mathrm{Y} f \mathrm{Y}, \mathrm{ER}, \mathrm{r}^{*} \mathrm{r}^{*}\right)
\end{aligned}
$$

Equation (II.3) shows that BOP $=0$ for various combinations of domestic income $(\mathrm{Y})$ and their corresponding domestic interest rates (r). Government expenditure (G), exchange rate (e) and foreign income (Yf) are positive variable shifters. The slope of the BOP curve shows the degree of capital mobility. If BOP curve is vertical, then there is no capital mobility. Perfect capital mobility is shown by a horizontal BOP curve. A horizontal BOP curve implies that there is no difference between foreign and domestic interest rates and as such there is no incentive for capital flows. The effectiveness of fiscal policy on MF model in an open economy depends on the degree of capital mobility and the exchange rate. Most East Asia countries including Indonesia, are open economies, however, there is only little foreign investment inflow. This implies that the slope of BOP curve is relatively steep or probably almost vertical, which apparently 
shows that there is a limited capital mobility. On these countries, the interest rate merely has no significant role on money demand, and depicted by a very steep LM curve.

Using MF model for a fixed exchange rate regime results in a more limited capital mobility and the slope of the LM curve either relatively more steeper or less flatter than those of BOP curve. Expansionary fiscal policy would shift IS curve to the IS (Romer, 2001; Sukirno, 2005). When BOP is steeper than LM curves, as shown in Figure II.1.(a), the new internal equilibrium (E1) causes deficit in BOP, since it lies below the BOP curve. If the Central Bank contractionally intervenes the money market in order to neutrelize the domestic currency deppreciation, the LM curve shifts to the left and this will decrease the effectiveness of fiscal expansionary policy. On another case where the BOP curve is flatter than the LM curve, as depicted in Figure II. 1.(b), the new internal balance (point $E_{1}$ ) shows a surplus in BOP since it lies above the BOP curve. In general, to reduce this surplus pressure and to maintain the fixed exchange rate due to the domestic currency appreciation pressure, the central bank wants to reduce the domestic-foreign interest rate differential by monetary expansionhence the money supply increases. When the LM curve shifts to the right and if the inflow of capital is not sterelized, then the effectiveness of fiscal policy would be enlarged. Therefore, under fixed exchange rate regime, the effectiveness of fiscal policy would be enlarged by the increasing of capital mobility.

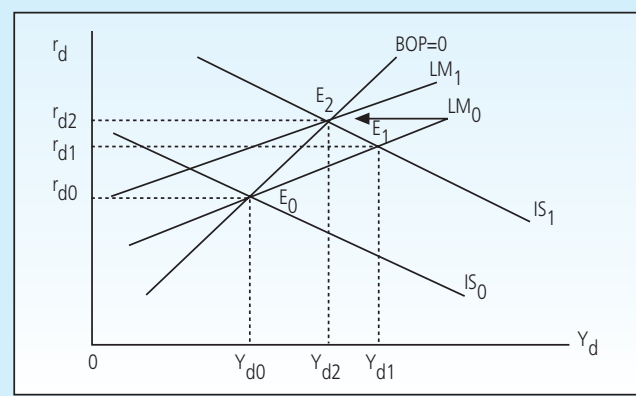

Source: Romer (2001), Sukirno (2005)

(a)

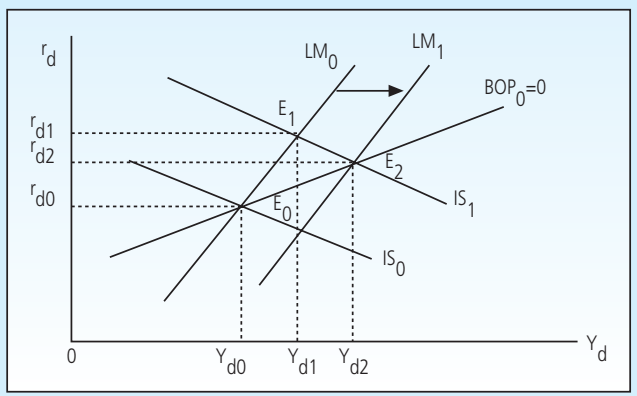

Source: Romer (2001), Sukirno (2005)

(b)

Figure II.1: The effectiveness of fiscal policy under fixed exchange regime and limited capital mobility

Figure II.2 shows the BOP curve under flexible exchange rate regime (Romer, 2001; Sukirno, 2005). If the BOP curve is steeper than the LM curve, as shown in Figure II.2.(a), fiscal expansionary policy would cause deficit in the BOP and real exchange rate is depressed. As such the competitiveness and export would increase, the IS curve will furhter shift to the right 
and so will the BOP curve. The new equilibrium is $E_{2}$ where the effectiveness of fiscal policy would be relatively larger than the case of fixed exchange rate regime.

If the BOP curve is flatter than the LM curve, as depicted by Figure II.2.(b), expansionary fiscal policy would create a surplus in the BOP. This surplus causes appreciation in real exchange rate, reduce competitiveness and thus decrease in exports. The last equilibrium, either IS curve or BOP curve shifts to the left until the new external and internal balances are achieved at point $E_{2}$. This concludes that under flexible exchange rate regime, the more sensitive of capital mobility on interest rate, the less effective the fiscal policy will be

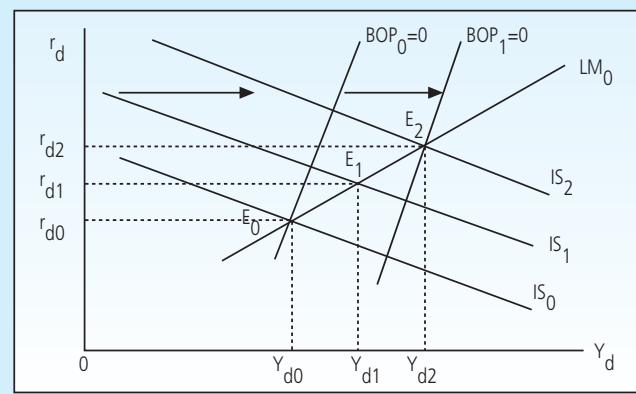

Source: Romer (2001), Sukirno (2005)

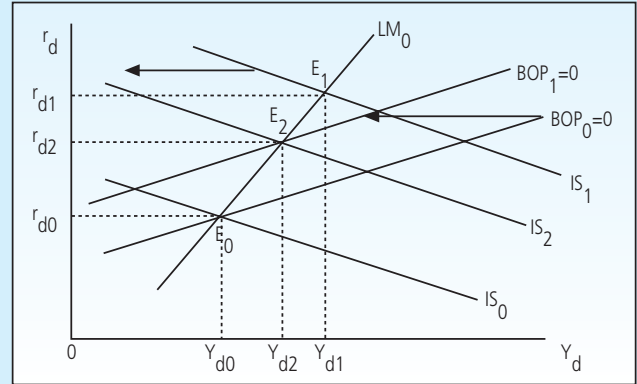

Source: Romer (2001), Sukirno (2005)

Figure II.2: The effectiveness of fiscal policy under flexibel exchange and limited capital mobility

\section{II.3. Government Revenue}

Sources of government revenue are tax, non-tax, and endowment. Tax covers central tax, which is collected by central government, and local tax which is collected by local government. Types of central tax are: (1) income tax (PPh), (2) value added tax on goods and services (PPn), (3) tax on the sales of luxurious goods (PPnBM), (4) quit rent and assesment (PBB), (5) real estate tax (BPHTB), (6) stamp duty, (7) excise tax, (8) export tax, and (9) entry tax (Hutahaean, et al, 2002).

Income tax (PPh) and value added tax (PPn) have a relatively a fast transmission effect on the change in saving behavior, investment, and firm expansion (James and Nobes, 1992). According to James and Nobes (1992), the behavior of households and firms in Indonesia is sensitive to a change in PPh and PPn. Consequently, government intervention to influence 
sectoral performance would be effective using the instruments of PPh dan PPn (Darsono, 2008). The combination analysis of income tax (PPh) and value added tax (PPn) are found in Atkinson and Stiglizt (1976), Mirrlees (1976), and Myles (1997). In this model, it is assumed that there are $n$ goods provided by the producer as good 1 and wage rate, $w$. Rule of normalization says that tax is linear toward $n$ goods. By this rule, a limited budget ( $q x$ ) faced by a consumer that has an ability to pay tax, $s$, and tax level $T$ is:

$$
\sum_{1=2}^{n} q_{i} \chi_{i}=s w x_{1}-T\left(s w x_{1}\right)
$$

In order to simplify derivation, production technology is assume to be linear so that production possibility is bounded by the following relationship:

$$
\sum_{i=2}^{n} \int_{0}^{\infty} x_{i}(s) \gamma(s) d s \leq \int_{0}^{\infty} s w x_{1}(s) \gamma(s) d s-z^{G}
$$

where, $\mathrm{z}^{\mathrm{G}}$ is the imposition of government on tax. The lenearity of technology enable us to derive producer's price for each good $2, \ldots, \mathrm{n}$ becomes 1 . The optimal tax could be attained by positioning $\mathrm{U}(\mathrm{s})$ as a real variable and $\mathrm{x}_{\mathrm{i}}(\mathrm{s}),, \mathrm{i}=1, \ldots, n-1$ as control variables. The $\mathrm{x}_{\mathrm{n}}(\mathrm{s}$,$) is$ determined by the identity of $\mathrm{U}(\mathrm{s})=\mathrm{U}\left(\mathrm{x}_{1}(\mathrm{~s}), \ldots, \mathrm{x}_{\mathrm{n}}(\mathrm{st})\right)$. The requirement of first order for self selection is derived by using the fact $u_{s}=-\frac{U_{1}^{2}}{s^{2}}=\frac{U_{1} l}{s}$ or in the notational form as.

$$
u_{s}=-\frac{U_{x_{l}} x_{1}}{s}
$$

The Hamiltonian first order condition for maximization can be written as equation

$$
H=\left\lfloor U+\lambda\left[s w x 1-\sum_{i-2}^{n} x i\right] \gamma(s)-\mu \frac{x_{l} U_{x_{l}}}{s}\right.
$$

In order to choose $\mathrm{x}_{\mathrm{k}}(\mathrm{s}), \mathrm{k}=2, \ldots, n-1$, the fact that being used is:

$$
\frac{\partial x_{n}}{\partial x_{k}}=-\frac{U_{x_{k}}}{U_{x_{n}}}
$$

The necessary condition for optimality is:

$$
-\lambda\left\lfloor 1-\frac{U_{x_{k}}}{U_{x_{n}}}\right\rfloor \gamma-\frac{\mu x_{1}}{s}\left\lfloor U_{x_{1} x_{k}}-U_{x_{1} x_{n}} \frac{U_{x_{k}}}{U_{x_{n}}}\right\rfloor=0, k=2, \ldots n
$$


From the above necessary condition, households maximize their utility as follows:

$\frac{U_{x_{k}}}{U_{x_{n}}}=\frac{1+t_{k}}{1}$

Substite equation (II.9) into equation (II.8) and rearrange terms to get an optimal tax $\left(\mathrm{t}_{\mathrm{k}}\right)$ that can be written as follow:

$$
t_{k}=\frac{\mu x_{1} U_{x_{k}}}{\lambda \gamma s}\left\lfloor\frac{d \log \left[\frac{U_{x_{k}}}{U_{x_{n}}}\right]}{d x_{1}}\right\rfloor, k=2, \ldots n-1
$$

\section{II.4. Government expenditure}

The connection between government consumption and its budget can be seen by looking at the public sector's financial balance as follows

$$
(T-C g-I g)=B g p+\Delta H+B g f
$$

where $T$ is tax revenue, $C g$ is government consumption, $I g$ is government investment, $B g p$ is government borrowing from private sector, $\Delta H$ is change in the stock of high-powered money, and $B g f$ is government borrowing from foreigners. The left-hand side of equation (II.12) shows the fiscal deficit while on the right-hand side shows the sources of fund. If the government desires to increase its expenditure, then the financing could be done by raising tax revenue without effecting fiscal deficit. The level of government consumption is determined by its revenue and outside financing for the budget deficit. In order to overcome a budget deficit, the government could initate the followings: (a) borrow from private sector, (b) money creation (c), borrow from abroad, (d) the reduction of devisa's saving, (e) privatisation, and (f) arrears accumulation.

Alternatively, to view fiscal position of the government is by looking at the economy's saving-investment balance. Mathematically, it is presented in equation (II.12).

$$
(T-C g-I g)=(S p-I p)+(M-X)
$$

where $T$ is tax revenue, $C g$ is government consumption, $I g$ is government investment, $S p$ is private saving, $I p$ is private investment, $M$ is import, $X$ is export, and $(M-X)$ is the external current account deficit. Equation (II.12) shows that the fiscal deficit is equal to the total savinginvestment gap from private sector and external current account deficit. Combining (II.11) and (II.12) to get the following equations: 


$$
\begin{aligned}
& S p-I p=B g p+\Delta H-B p f \\
& M-X=B g f+B p f
\end{aligned}
$$

where $B p f$ is borrowing from foreign and private sector.

Equation (II.13) states that the surplus of private sector saving is equal to government borrowing plus its own money minus its foreign debt. Equation (II.14) states that external current account deficit is financed by government's foreign debt and private's foreign debt. The source of foreign debt is foreign saving. Subtituting (II.13) and (II.14) into equation (II.12) to get equation (II.11).

\section{II.5. Subsidy and Direct Cash Aid}

Subsidy is a payment by the government to firm or household in order to attain certain goals which eventually enables them to produce or consume a product in a bigger quantity or at a cheaper price. The goal of a subsidy is to decrease the price of a good or to increase the quantity of output (Spencer \& Amos, 1993). According to Suparmoko (2003), subsidy or transfer of payment is a sort of government expenditure which is also known as a negative tax and eventually would increase the income of the subsidy receipient or the consumer realizes an increase in real income if they consume a subsidised good. There are two types of government subsidies - transfer of cash and in kind subsidy. Cash transfer is given to the consumer as an additional income or if it is given to producers it is expected that a lower product price. In kind subsidy is a subsidy in which a receipient received a quantity of a good without paying it (Handoko dan Patriadi, 2005). Subsidy is a form of government expenditure to help the people for their basic needs at an affordable price. Also, a subsidy is given to help the producer to produce enough quantity of a basic need type of good at an affordable price to the sosiety. The subsidy is aimed to stabilize the economy, especially price stability. Subsidy is expected to keep the existing raw materials in a ready stock and to ensure its price is affordable (Nota Keuangan \& APBN, 2010). In many developing countries, subsidy is very important to enhance productivity and welfare (Norton, 2004). Subsidy is an efficient way of transfer of payment from the government to the people as a way of welfare redistribution. Welfare redistribution is the bottomline of a subsidy.

The effect of a government subsidy, especially for agricultural products, is shown in Figure II.3. An agricultural product supply curve in a short run (SR) is assumed to be inelastic as shown in Figure II.3(a). If the government pays subsidy for agricultural production, then the impact would be an increase in the product demand, i.e. the demand curve shifts to the right and 


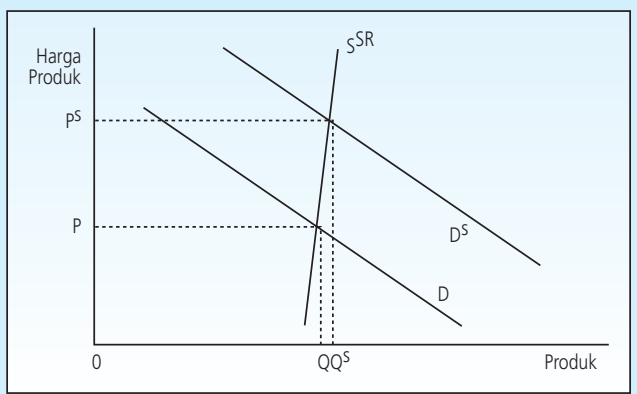

Source : Stiglitz (2000)

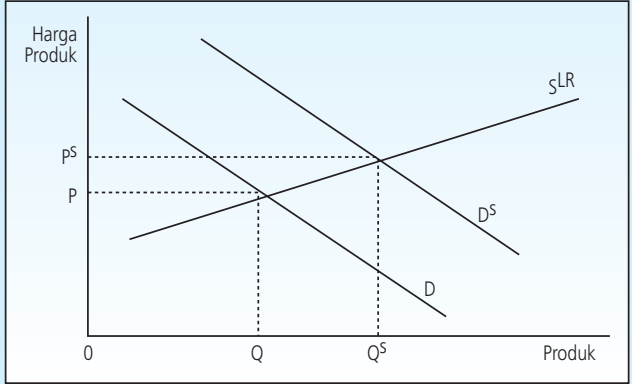

Source : Stiglitz (2000)

Figure II.3:

The Effect of Subsidy on Agricultural Production

above. An increase in demand leads to an increase in price but the farmers are unable to increase their production. However, in the long run (LR), subsidy on agricultural production leads to an increse in quantity supplied because in the $L R$, supply curve is more elastic as shown in panel (b), Figure II.3.

The effect of subsidy on consumption and production can be analyzed by looking at the demand curve as well as the supply curve. Subsidy shifts demand curve to the right and above as well as a shift to the right and below for a supply curve of a subsidised good. The result of both of these subsidies is a bigger new equilibrium quantity of goods. The influence of these two subsidies in demand and supply are shown Figure II.4. In Figure II.4(a) subsidy on consumption shifts demand curve D to $D^{\prime}$. While in Figure II.4 (b), subsidy on production shifts supply curve $S$ to $S^{\prime}$.

The elasticity effect on supply and demand curves are displayed in Figure II.5. If the demand curve is perfectly inelastic, as shown in Figure II.5 (a), subsidy shifts supply curve from $S$ to the $S^{\prime}$. The equilibrium quantity remains the same but price will decrease. If the demand is perfectly elastic, as shown in panel (b), Figure II.5, the effect of subsidy is an increse in equilibrium quantity at the same price. If the supply curve is perfectly elastic, subsidy increases the equilibrium quantity, as shown in panel (c).

The government policy on subsidy is usually related to the goods and services that have a positive externality. While negative effect from subsidy is creating ineffective allocation because the consumer lavishly consumed a subsidized good. Also, since price is lower than opportunity 

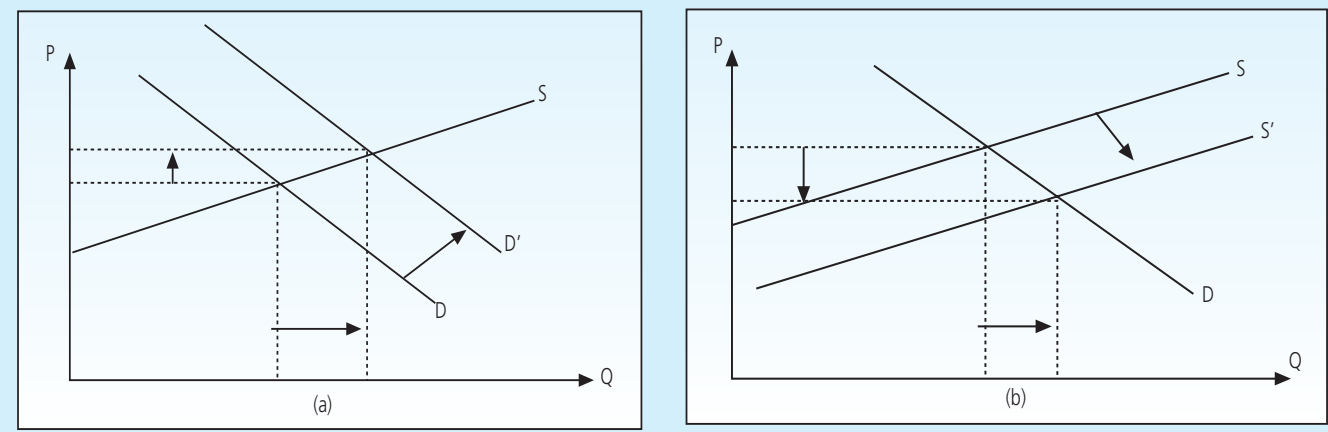

Figure II.4:

The Effect of Subsidy on Demand and Supply
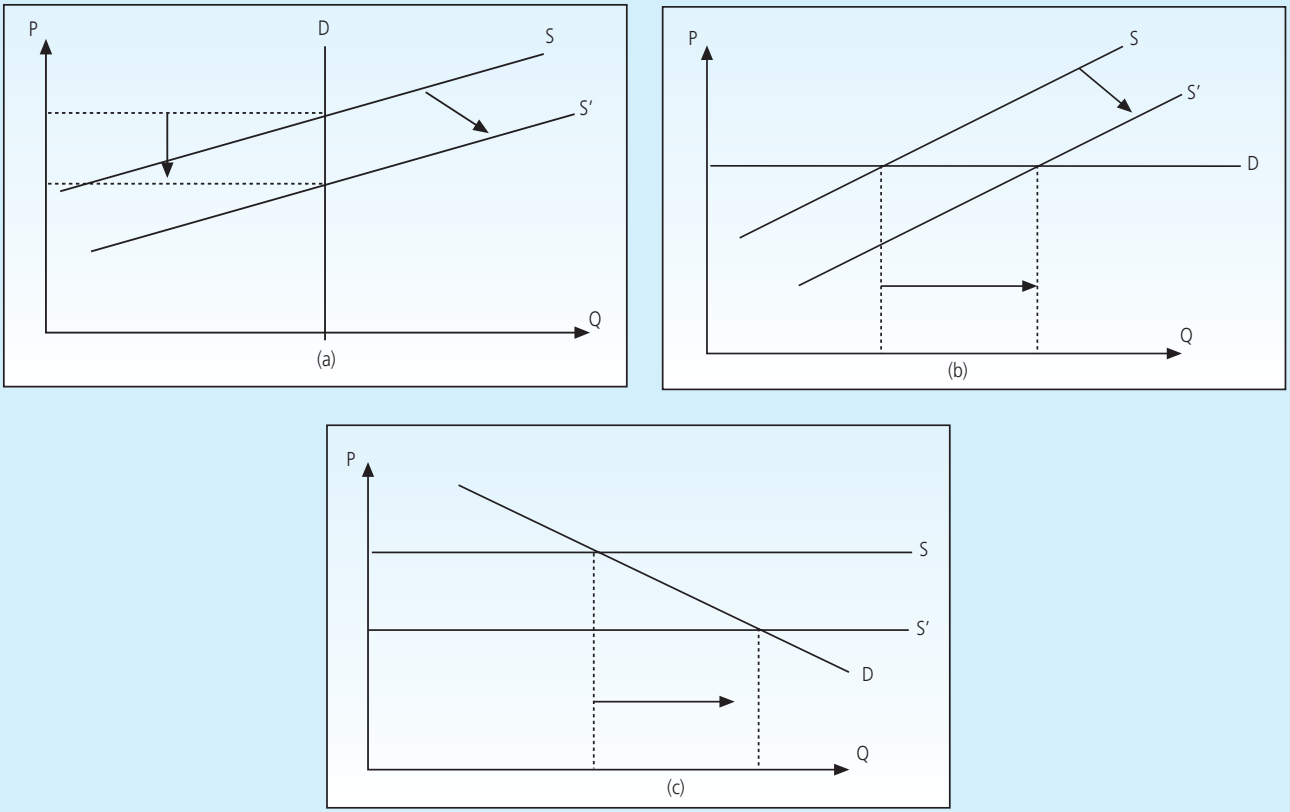

Figure II.5:

The Effect of Subsidy in a Perfectly and Inperfectly Elastic

cost, there is a possibility for producer to be inefficient in using resources to produce subsidized goods (Spencer \& Amos, 1993). Subsidy which is not transparent and not well targeted possibly cause price distortion, ineffeciency, and enjoyed by non-deserve people (Basri, 2002). 


\section{II.6. The effect of government expenditure}

The impact of an increase in government expenditure on output advancement relied on multiplier effect of that policy that could be explained using the IS-LM approach. The IS curve shows the balance in goods market, while the LM curve shows the balance in the money market. Systematically, these two balances could be written in equations (II.15) and (II.16), respectively.

$$
\begin{aligned}
& y=c\left(y-t_{(y)}\right)+i_{(r)}+g \\
& \frac{M}{P_{0}}=l_{(r)}+k_{(y)}
\end{aligned}
$$

Consumption function and tax have a positive slope but smaller than one $\left(0<c^{\prime}, t^{\prime}<1\right)$. Investment slope, money demand and money demand transaction are $i^{\prime}<0, l^{\prime}<0$, and ( $k^{\prime}>0$ symbol ' shows a certain value). Equations (II.15) and (II.16) are derived by assuming $\frac{M}{P}$ is constant, then we get equations (II.17) and (II.18).

$$
\begin{aligned}
d y & =c\left(d y-t^{\prime} d y\right)+i^{\prime} d r+d g \\
d y & =c\left(1-t^{\prime}\right) d y+i^{\prime} d r+d g \\
0 & =l^{\prime} d r+k^{\prime} d y \\
d r & =-\frac{k^{\prime}}{l^{\prime}} d y
\end{aligned}
$$

Subtituting (II.18) into (II.17) to get equation (II.19).

$$
d y=\frac{1}{1-c^{\prime}\left(1-t^{\prime}\right)+\frac{i^{\prime} k^{\prime}}{l^{\prime}}} d g
$$

Since $c^{\prime}\left(1-t^{\prime}\right)<1$ and $\frac{i^{\prime} k^{\prime}}{l^{\prime}}$ has a positive value, then this multiplier would be positive. The slope of LM curve is $-\frac{i^{\prime} k^{\prime}}{l^{\prime}}$ shows a decrease in investment triggered by an increasing in $r$ when $y$ and $r$ increase along LM curve. If LM curve is horizontal, i.e zero sloped, then the multiplier would be:

$$
d y=\frac{1}{1-c^{\prime}\left(1-t^{\prime}\right)} d g=\frac{1}{1-M P C} d g
$$

The implication of equation (II.20) is that eventhough the government spending is at a low level, it has an impact on output. In other words, the change in output is relatively bigger 
if LM curve is relatively flat, i.e. when the slope of the LM curve approaches zero.

BPS uses the concept of basic needs approach in measuring poverty in Indonesia. This approach views poverty as the incapability of the economy to fullfil the food and non-food basic need, that is measured using household expenditure. Using this approach, three measures of poverty, i.e. Headcount Index that is those people who are living under poverty line, poverty depth index (P1) and poverty severity index (P2) are able to be computed.

The method used is computing poverty line, consist of two components, they are food poverty line (GKM) and non-food poverty line. The measurement of poverty line are computed separately for urban and rural areas for each province. Poor people are those monthly per capita income is below the poverty line.

The food poverty line is the expenditure value of minimum need for food which is equivalent with 2100 kilocalories percapita per day. The basket of commodities of the basic need consists of 52 items, among others are rice, fish, meat, eggs, milk, vegetables, beans, fruits and oil.

\section{METHODOLOGY}

This study employs a Computable General Equilibrium (CGE) model, which was formulated by the International Food Policy Research Institute (IFPRI). This model refers to the standard of CGE model developed by Lofgren, et al. (2002), Decaluwe Decaluwé, et al. (1998; 1999), and Cockburn (2001). For the purpose of this study, the first step is identifying the assumption, structure, basic data, production function, closure and endogenous and exogenous variables. The next step is identifying the sectors that utilize basic data from Input-Output (IO) Table, Socio-Economic Balance Sheet System and the National Socio-Economic Survey. The mechanism of the fiscal policies' transmission which is the basis for this research can be summarized in Diagram II.1.

This study focuses on fiscal policy as follows: (1) non-direct tax, (2) government subsidy for electricity, gas and water; transportation and communication; and manufacturing sectors, and (3) direct transfer of payment to households. For the purpose of this study, we follow BPS classification of households, namely (i) rural agricultural labor, (ii) rural agricultural enterpreneur, (iii) rural low-income non-agricultural labor, (iv) rural non-labor force and undefined group, (v) rural high-income non-agricultutal labor, (vi) urban low-income nonagricultural labor force, (vii) urban non-labor and undefined group, and (viii) urban highincome non-agricultural labor. 


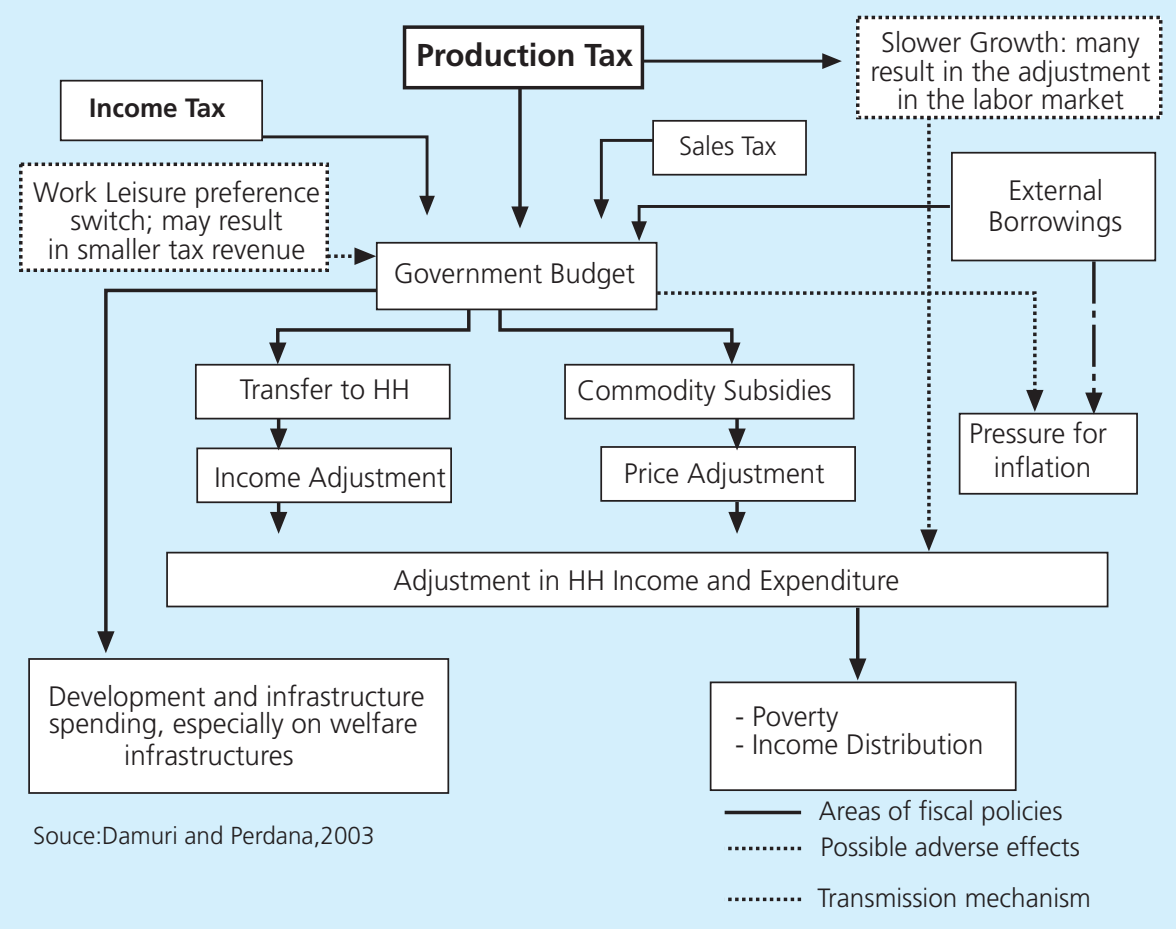

Diagram II.1

The Mechanism of Fiscal Policies' Transmission in Affecting Income Distribution and Poverty

Identification of the structure of the production function is crucial for this study. The structure and the behavior of various production process can be formed of Leontief function, constant elasticity of transformation (CET), and constant elasticity of substitution (CES). Elasticities and other parameters of respective functions could be estimated outside the model or quoted directly from various previous studies. The next step is updating basic data from year 2003 to year 2005 using Cross-Entropy method. The data obtained, either from the estimation or the results of the past studies are validated or tested for its consistency, hence considered to be relevant.

Once the data and the model are in order, then the fiscal simulation will be carried out. The simulation conducted in this study is for a fiscal adjustment, such as taxes, subsidies, and transfer of payments to households. The outcomes of these simulations will then be evaluated, in terms of macro and micro terms. The macro conditions are the changes in gross domestic product, inflation rate, trade balance, and unemployment rate, while the micro side views through changes in income distribution and poverty in Indonesia. Diagram II.2 presents the concept of the research design. 


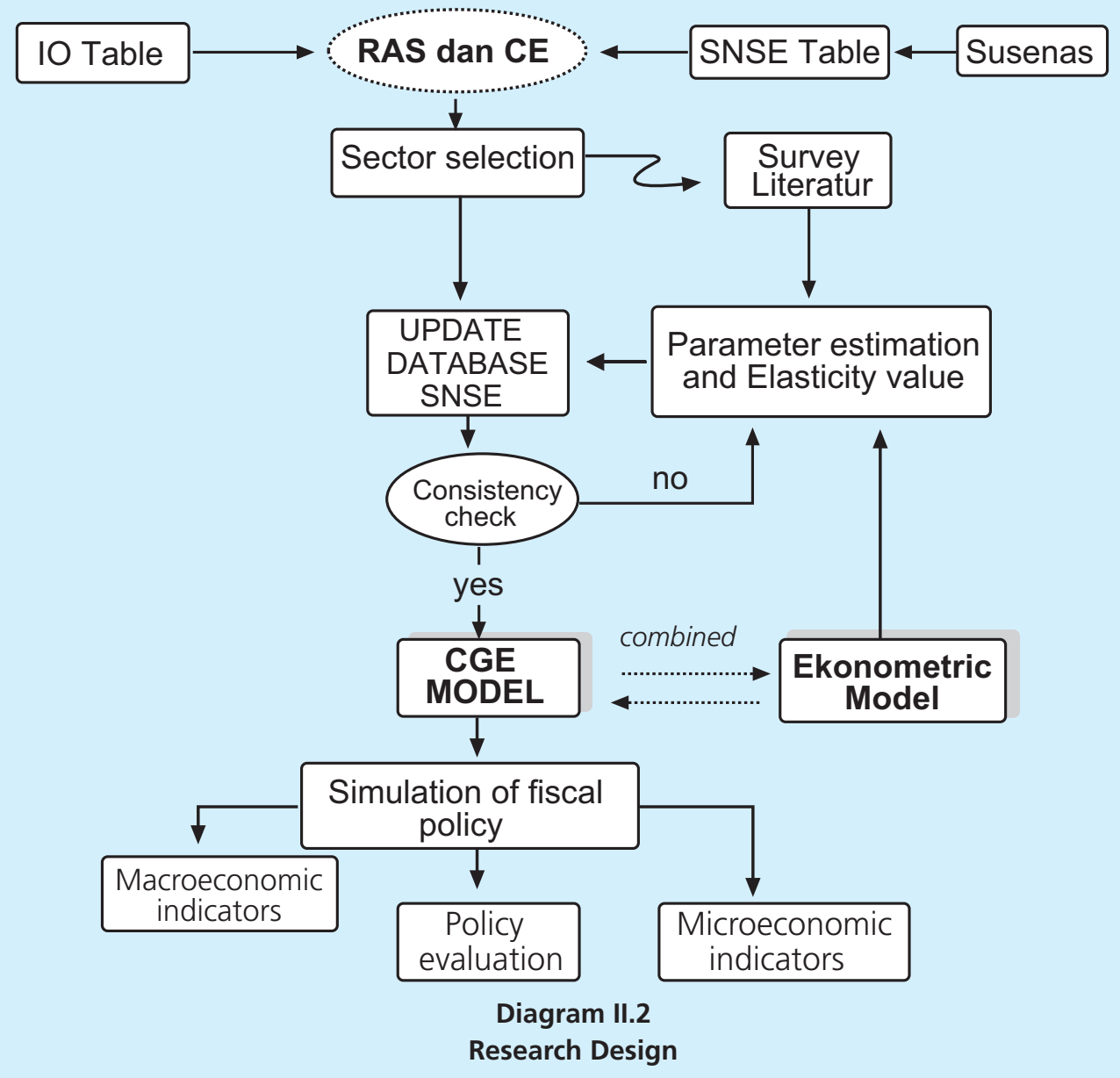

\section{III.1. Poverty Measurement and Income Distribution}

To analyze poverty based on household groups, it is suggested that an income distribution formula based on the characteristic of household groups is used. This distribution relies on maximum and minimum income and on the skewness in income distribution. In order to bring this characteristic to the income distribution, beta distribution function is used as suggested by Decaluwé, et. al (1999), as follows:

$$
I(y ; p, q)=\frac{1}{B(p, q)} \frac{(y-m n)^{p-1}(m x-y)^{q-1}}{(m x-m n)^{p+q-1}}
$$


Where

$$
B(p, q)=\int_{m n}^{m x} \frac{(y-m n)^{p-1}(m x-y)^{q-1}}{(m x-m n)^{p+q-1}} d y
$$

Parameter $m x$ and $m n$ are maximum and minimum income within a group. Parameters $p$ and $q$ would influence the form and the distribution skewness. This distribution based on certain distribution beta parameter which is estimated from various statistical parameters. The relation between parameter $p$ and $q$ in beta distribution function and various statistical parameters could be explained by using the following formula:

$$
p=\bar{x}\left(\frac{\bar{x}(1-\bar{x})}{s^{2}}-1\right) \quad \text { and } \quad q=(1-\bar{x})\left(\frac{\bar{x}(1-\bar{x})}{s^{2}}-1\right)
$$

where is the mean sample and $\mathrm{s}^{2}$ is the variance sample which are derived by the following:

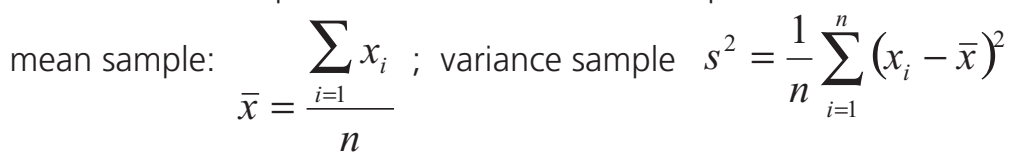

If $p>q$, then the distribution skewed to the left and this situation lead to larger disparity between $p$ and $q$. The same applies when $q>p$, then the distribution skewed to the right that shows disparity increasing. If $p=q$, then the function is symmetric. These three conditions are true if the value taken by $p$ and $q$ is bigger than one. The distribution function as shown in equation (II.21) is used to evaluate poverty incidence in each group of household in the general equilibrium economy model. If the average of income is $\psi$, then income in each household in the group increases by $\psi$. By this rule, income distribution proportionally would change horizontally following the change in income.

The above procedure allows us to compare poverty rate created in the post- and presimulation using the measurement developed by Foster, Greer and Thorbecke (F-G-T), Pa. The measurement of $\mathrm{Pa}$ is expressed in Beta distribution. The F-G-T formula is:

$$
P_{\alpha}=\int_{m n}^{z}\left(\frac{z-y}{z}\right)^{\alpha} I(y ; p, q) d y
$$

where $a$ is poverty-aversion parameter, $z$ is poverty line, and $m n$ is minimum income intragroup while $p$ and $q$ are the parameter from beta function as defined before.

Poverty line measure as shown in the equation of monetary poverty line (II.24) is determined endogenously in the CGE model. It is postulated that the poverty line as determined by the basket of commodities shows the consumption of the basic needs. This is consistent with 
Ravallion (1994) method in estimating absolute poverty, $\gamma_{c h}^{m}$. That is:

Monetary Poverty Line: $\sum_{c \in C} P Q_{c} \cdot \gamma_{c h}^{m}$

Since the price of commodity is determined endogenously in the model, then the nominal value of this basket is the poverty line. If the increasing in the price of a commodity follows certain external shock, then the poverty line, $z$, would increase (shifted to the right) and so would the poverty, ceteris paribus. The demand system determined in this model is based on a linear expenditure system (LES), that is:

$$
P Q_{c} \cdot Q H_{c h}=P Q_{c} \cdot \gamma_{c h}^{m}+\beta_{c h}^{m} \cdot\left(E H_{h}-\sum_{c \in C} P Q_{c} \cdot \gamma_{c h}^{m}\right)
$$

where $Q H_{c h}$ is the quantity of commodity consumption $c$ marketed by household $h$, and is subsistence consumption commodity $c$ marketed by household $h$, and is marginal share from consumption expenditure $c$ marketed by households $h$.

\section{III.2. Production Activity and Factor Market}

In this model, each producer is assumed to maximize their profits. Profit is defined as the difference between total revenue and total costs of using factor of production and intermediate inputs, for a given level of technology. Production functions can be in any form such as Leontief, CES, Cobb-Douglas, and Translog, depends on its underlying theoretical and empirical assessment. The constant elasticity of substitution (CES) function is a function that is favored by certain sectors. Value added is determined by CES function from primary factors to allow the substitution between one factor say labor to capital and vice versa. On upper nesting form, the composite intermediate input is combined from each input in Leontief function, implies no substitution among intermediate input.

\section{III.3. Institution}

In the CGE model, institutions consist of households, firm, government and the rest of the world (RoW). Households receive income from the factor of production and transfer from other institutions. Transfer from RoW to the households is in foreign currency and treated exogenously hence fixed. In this model, direct tax and transfer to other domestic institutions defined as fixed share from household income, except for flexible share savings for chosen 
households. Households consumption includes marketed commodity, purchased at the market price including commodity tax and transaction cost. Households consumption is allocated across different commodities according to demand function of Linier Expenditure System (LES), derived from the maximization of Stone Geary utility function (Dervis et. al. 1982, pp. 482-485).

The government collects tax and receives transfer from other institutions. In the version of basic model, all tax settled at fixed ad-valorem. The government uses this income to purchase commodity for its consumption and for transfer to other institutions. Government expenditure is fixed in terms of real quantity except government transfer to domestic institutions which is indexed to the consumer price index (CPI). The government saving is flexible and residually determined.

The last institution is RoW. Payment transfer between RoW with other domestic institutions and all factors are fixed in foreign currency. Foreign saving is the difference between expenditure and income in foreign currency.

\section{III.4. Commodity Market}

The CES function in the survey model is used as an aggregate function. The output demand from respective activities derived from cost minimization problem subject to certain offered quantity of output.. The next step, domestic aggregate output allocated between export and domestic selling with the assumption that the producer maximize selling under assumption of imperfect transformability between export and domestic selling. This is expressed by Constant Elasticity of Transformation function (CET). In the international market, export demand is infinitely elastic for certain world price. The total of market demand is the sum of domestically produced output and direct import.

The demand of import commodity is attained from international producer which is infinitely elastic on world price. Import price paid by the domestic consumer includes import tariff (at fixed ad-valorem rates) and certain transaction costs per unit import to deliver the commodity from the borders to the consumers. The transaction cost here is not ad-valorem. The assumption of imperfect transformability (between export and domestic selling) and imperfect substitutability (between import and domestic output sold domestically) lead this model relatively better in depicting empirical reality from most of the countries. These assumptions allow certain degree of independence of domestic economy from international price, hence avoid the unrealistic respond of export and import from economy shock. 


\section{III.5. Macroeconomic Balances}

The CGE Model that is established includes three macro balances. These balances are current government balance, external balance (current account of the balance of payment, including trade balance), and Saving-Investment balance. For government balance, closure that is used is government saving which is residual flexible while all tax is fixed. Government consumption also fixed, either in the real term or as share of nominal absorption. For external balance, expressed by foreign currency, closure that is used is real exchange rate which is flexible while foreign savings (current account deficit) is fixed. If other components is given as fixed in external balance (transfer between RoW and domestic institutions), thus the trade balance is also fixed. Ceteris paribus, if foreign saving is endogenously determined, then depreciation from real exchange rate would correct this situation simultaneously either by decreasing expenditure on import and or by increasing income from export.

On Saving-Investment balances closure, we choose to use the investment driven. Real investment quantity is held fixed. In order to maintain the same level of real initial investment, the saving level in the base year of the non government institution is adjusted at one point with the same percentage quantity. Implicitly, this invesetment closure enable the government to implement the policy in order to produce private saving which is needed to finance certain real investment. The combination from these three closures in the macro-closure literature is known as Johansen Closures. The type of this closure has been used in CGE model developed by Leif Johansen (1960).

In summary, the closures utilized in this research is (i) government savings is fixed as well as direct tax (ii) the foreign savings is fixed while the exchange rate is flexible, (iii) the capital establishment is fixed as well as the real investment quantity.

\section{III.6. Model Equation}

In order to analyze fiscal policy in this study, the CGE standart model is used for open economy developed by Hans Löfgren from International Food Policy Reseach Institute (IFRI). This model is operated by using software GAMS (General Algebraic Modeling System). The equation in the model is devided into four blocks, namely price, production and trade, institutions, and obstacle systems.

The equations that have been built previously form the model of distribution and poverty in Indonesia. The following sample shows how the equations work process on the model run and produce a converged solution. Calibration process can be referred to as the process of mathematical manipulation of certain equations. Calibration process is performed to obtain 
the distribution parameters and the efficiency parameters of the equation's function. For example, assume the economy has a production function reflected by the constant elasticity of substitution (CES):

$$
y=\alpha\left[\beta X_{1}^{-\rho}+(1-\beta) X_{2}^{-\rho}\right]^{-\frac{1}{\rho}}
$$

where $\alpha$ is an efficiency parameter in that it merely shifts the whole function, $\beta$ is a distribution parameter that permits the relative importance of $X_{1}$ and $X_{2}$, and is the substitution parameter. Pareto efficiency occurs when the general equilibrium is reached through the mechanism of a perfectly competitive market, i.e. when all the three functions - consumption, production, and product mix are in simultenous equilibrium.

\section{RESULT AND DISCUSSION}

The intended fiscal policy in this study covers only: (1) indirect taxes, (2) government subsidy on electricity, gas and water, transportation, and industry, and (3) direct transfer of payment to households. The impact of these fiscal policy measures will be discussed to assess the performance of some macroeconomic variabels, such as Gross Domestic Product (PDB), consumer price index, trade balance, aggregate output, aggregate labor, investment rate, and household consumption.

\section{IV.1. The Impact of Contraction and Expansion of Fiscal Policy on Indonesian Macro Economic Performance}

Table II.1 shows the simulation results of various contraction and expansion of fiscal policy by 10 percent. Simulation 1 is an increase of indirect tax. The results of simulation 1 generally have a negative impact on Indonesian macroeconomic performance. This is represented by a decreasing in GDP by 0.005 percent. The decline in Indonesia economic performance is influenced by the decline in government consumption as well as private consumption, exports, and imports. Although the imports is declined but the export also declined as well which finally driven to a decline in GDP.

On the other hand, if the government conducted expansionary fiscal policy such as an increase in subsidy by 10 percent, as shown in simulation 2, the GDP increases by 0.106 percent. The provision of subsidy acts as an incentive to the producer which eventually lowers the price and increase demand (private and government). Interestingly, an increase in subsidy increases exports and investment. 


\begin{tabular}{|c|c|c|c|}
\hline Variable & Simulation 1 & Simulation 2 & Simulation 3 \\
\hline Absorption & -0.010 & 0.141 & -0.002 \\
\hline Private consumption & -0.026 & 0.059 & -0.001 \\
\hline Investment & 0.110 & 0.178 & -0.004 \\
\hline Government Consumption & -0.124 & 0.807 & 0.001 \\
\hline Export & -0.040 & 0.310 & -0.019 \\
\hline Import & -0.064 & 0.487 & -0.021 \\
\hline GDP by expenditure & -0.005 & 0.106 & -0.002 \\
\hline GDP by production & -0.005 & 0.106 & -0.002 \\
\hline
\end{tabular}

Simulation 1: An increase of indirect tax by $10 \%$ for the whole activity of economic sector

Simulation 2: An increase of government subsidy by $10 \%$ in all production sector

Simulation 3: An income transfer amounting Rp. 100000,- to rural household groups from the actual average income of respective households

Next, the impacts of simulation 3 which is a government transfer of payment amounting Rp. 10000,- to rural households are examined. The overall results show that transfer of payment to households has a small decline in real GDP. Real GDP decreases by 0.002 percent.

\section{IV.2. The Impact of an Increase in Tax on Economic Performance}

This sub-section overviews the impacts of expansion and contraction of fiscal policy on sectoral economic performance. For the purpose of this study, the analysis is focused on an increase in tax on the change in sectoral output, output price, and labor absorption.

\section{IV.2.1. The Impact of an Increase in Tax on Sectoral Economic Performance}

Table II. 2 reveals the impact of an increase in tax by 10 percent on sectoral output, output price, and labor absorbtion. It is found that an increase in tax has a positive impact on various sectors with the exception of manufacturing industry; and trade, hotel, and restaurant. Manufacturing industry and trade, hotel, and restaurants show a negative impact of an increase in tax on output performance. An increase in tax results in an increase in output price for all sectors. This result shows that producers are able to pass the tax burden on consumers. An increase in tax also reduces labor absorbtion rates for two sectors, namely Manufacturing industry; and Trade, Hotel, and Restaurants. Even thought producers are able to pass the tax burden to consumers in the form of higher output prices, the output for these two sectors are affected negatively. Consequently, the their demand for labor also decrease as a result of an increase in tax. 


\begin{tabular}{|c|c|c|c|}
\hline Sector & Output & Price & Labor \\
\hline Sector & Output & Price & Labor \\
\hline Agriculture & 0.254 & 0.999 & 0.325 \\
\hline Mining and Quarrying & 0.301 & 0.966 & 0.996 \\
\hline Manufacturing Industry & -0.317 & 0.993 & -0.662 \\
\hline Electricity, Gas, and Clean Water & 0.463 & 0.993 & 1.567 \\
\hline Construction & 0.004 & 0.999 & 0.007 \\
\hline Trade, Hotel, and Restaurants & -0.189 & 1.009 & -0.230 \\
\hline Transportation and Communications & 0.020 & 1.006 & 0.040 \\
\hline Finance, leasing, and Business Service & 0.184 & 1.010 & 0.572 \\
\hline Other Services & 0.175 & 1.006 & 0.260 \\
\hline
\end{tabular}

\section{IV.2.2. The Impact of an Increase in Tax on Income and Poverty}

The next effort is to analyze the impact of an increase in tax by 10 percent on the household utility, income, and expenditure. Table II.3 displays the results of the simulation. The results show that the impact of an increase in tax on utility varies depending on the classification of households. Rural agricultural labor and entrepreneur have their utility increased by less than 5 percent. However other household groups experienced a decrease in their utility by less than 1 percent.

An increase in tax has a negative impact on real income for all groups of household. As expected, an increase in tax can be translated into an increase in price, thus decline in the consumer's purchasing power. The declining in the purchasing power is in the same direction with the declining of household's expenditure, except for the households of the rural agricultural labor and entrepreneur.

Tabel II.3 Simulation Results on the Impact of an Increase in Tax on Utility, Income, and Expenditure of Households (\%)

\begin{tabular}{|c|c|c|c|c|}
\hline No & Household classifications & Utility & Income & Expenditure \\
\hline $\begin{array}{l}1 \\
2 \\
3 \\
4 \\
5 \\
6 \\
7 \\
8\end{array}$ & $\begin{array}{l}\text { Rural agricultural labor } \\
\text { Rural agricultural entrepreneur } \\
\text { Rural low-income non-agricultural labor } \\
\text { Rural non-labor force and undefined group } \\
\text { Rural high-income non-agricultural labor } \\
\text { Urban low-income non-agricultural labor } \\
\text { Urban non-labor force and undefined group } \\
\text { Urban high-income non-agricultural labor }\end{array}$ & $\begin{array}{r}0.341 \\
0.101 \\
-0.055 \\
-0.008 \\
-0.053 \\
-0.118 \\
-0.065 \\
-0.092\end{array}$ & $\begin{array}{l}-0.621 \\
-0.888 \\
-0.973 \\
-0.925 \\
-1.002 \\
-1.014 \\
-0.956 \\
-1.030\end{array}$ & $\begin{array}{r}0.270 \\
0.060 \\
-0.085 \\
-0.026 \\
-0.048 \\
-0.114 \\
-0.038 \\
-0.072\end{array}$ \\
\hline
\end{tabular}

Since an increase in tax has a negative impact on household's income, it is expected that the incidence of poverty might increase too. This study employs Foster-Greer-Thorbecke (F-GT) index as a measure of poverty. Commonly, poverty is measured using monetary unit. The 
World Bank's standard for poverty line is US $\$ 2 /$ day or equivalent to Rp. 559,000/month. Poverty line is the monetary value of a basket of commodities which mirrors the consumption of basic needs. An increase in tax is expected to affect poverty ratio index (head count index or poverty incidence), poverty disparity index (poverty depth), and poverty intensity index (poverty severity) of household. Table 4 reveals the results of the simulation of an increase in tax on poverty measures for various categories of household.

Based on poverty indicators (head count index, poverty depth and poverty severity), it is found that an increase in tax increases poverty intensity, poverty disparity, and poverty ratio for all groups of household. Generally, the impact of an increase in tax on poverty rate is higher on household in urban area compared to those in rural area.

\begin{tabular}{|c|c|c|c|c|}
\hline \multirow{3}{*}{ No } & \multicolumn{4}{|c|}{$\begin{array}{c}\text { Tabel II.4 } \\
\text { Simulation Results on the Impact of an Increase in Tax on thr chsnge in Poverty }\end{array}$} \\
\hline & \multirow{2}{*}{ Household classifications } & \multicolumn{3}{|c|}{$\%$ Change } \\
\hline & & $\alpha=0$ & $\alpha=1$ & $\alpha=2$ \\
\hline 1 & Rural agricultural labor & 0.7787 & 1.4103 & 1.6409 \\
\hline 2 & Rural agricultural entrepreneur & 1.4580 & 2.1222 & 2.4649 \\
\hline 3 & Rural low-income non-agricultural labor & 1.4074 & 2.0999 & 2.5169 \\
\hline 4 & Rural non-labor force and undefined group & 1.3666 & 2.0301 & 2.4236 \\
\hline 5 & Rural high-income non-agricultural labor & 1.6037 & 2.2153 & 2.6600 \\
\hline 6 & Urban low-income non-agricultural labor & 2.6043 & 2.7928 & 3.0850 \\
\hline 7 & Urban non-labor force and undefined group & 2.2276 & 2.7046 & 2.9039 \\
\hline 8 & Urban high-income non-agricultural labor & 2.7778 & 2.8869 & 3.1413 \\
\hline
\end{tabular}

\section{IV.3. The Impact of an Increase in Subsidy on Economic Performance}

This section discusses the impact of an increase in subsidy on sectoral economic performance With a simulation of government increases subsidy by 10 percent. It is expected that this increase in subsidy has a positive impact on sectoral economic performance because of subsidy lowers cost of doing business. Overall, an increase in subsidy by 10 percents resulted in an increase in GDP by 0.106 percent. The impact of subsidy on sectoral output, price, and labor absorbtion are discussed below.

\section{IV.3.1. The Impact of an Increase in Subsidy on Sectoral Economic Performance}

The simulation results of an increase in subsidy by 10 percent on output, price, and labor demand are displayed in Table II.5. An increase in subsidy has a positive impact on output for Manufacturing industry and public utility sector namely Electricity, Gas, and Clean water. Other sectors show a decline in output. 
The impact of an increase in subsidy reveals a different picture on output price. An increase in subsidy resulted in a decrease in price for several sectors, i.e. Mining and Quarrying, Manufacturing industry, and public utility. An increse in output in manufacturing industry and public utility sectors has a positive effect on labor demand. Manufacturing industry is able to absorb 3.73 percent new workers and public utility sector (Electricity, Gas, and Clean water) creates 10.69 percent new job vacancy.

\section{Tabel II.5}

Simulation Results of an Increase in Subsidy on Sectoral Economic Performance (\%)

\begin{tabular}{|c|c|c|c|}
\hline Sector & Output & Price & Labor \\
\hline $\begin{array}{l}\text { Agriculture } \\
\text { Mining and Quarrying } \\
\text { Manufacturing Industry } \\
\text { Electricity, Gas, and Clean Water } \\
\text { Construction } \\
\text { Trade, Hotel, and Restaurants } \\
\text { Transportation and Communications } \\
\text { Finance, leasing, and Business Service } \\
\text { Other Services }\end{array}$ & $\begin{array}{r}-0.798 \\
-0.943 \\
1.724 \\
3.022 \\
-0.037 \\
-0.219 \\
-0.557 \\
-0.631 \\
-1.172\end{array}$ & $\begin{array}{r}1.966 \\
-0.057 \\
-1.614 \\
-5.730 \\
0.397 \\
1.642 \\
0.823 \\
0.870 \\
1.132\end{array}$ & $\begin{array}{r}-1.004 \\
-2.950 \\
3.731 \\
10.693 \\
-0.033 \\
-0.256 \\
-0.998 \\
-1.831 \\
-1.696\end{array}$ \\
\hline
\end{tabular}

Those sectors that experience an incraese in price as a result of an increase in subsidy show a decrease in output. As such, labor demand is affected in a negative manner. Most likely government subsidy is relatively small compared to intermediate input price and therefore there is little impact on input price. The end result is a decline in output and an increase in price.

\section{IV.3.2. The Impact of an Increase of Subsidy on Income and Poverty}

This sub-section discusses the simulation results of an increase in subsidy by 10 percent on income and poverty among households as displayed in Table II.6. It is found that an increase in government subsidy has a positive impact on household income. However, household utility

\section{Tabel II.6}

Simulation Results of an Increase in Subsidy on Utility and Household Income (\%)

\begin{tabular}{c|l|c|c|c} 
No & Household classifications & Utility & Income & Expenditure \\
1 & Rural agricultural labor & -0.857 & 1.383 & -0.636 \\
2 & Rural agricultural entrepreneur & -0.186 & 2.024 & -0.145 \\
3 & Rural low-income non-agricultural labor & -0.045 & 2.227 & 0.189 \\
4 & Rural non-labor force and undefined group & 0.107 & 2.157 & 0.095 \\
5 & Rural high-income non-agricultural labor & 0.172 & 2.371 & 0.178 \\
6 & Urban low-income non-agricultural labor & 0.193 & 2.309 & 0.239 \\
7 & Urban non-labor force and undefined group & 0.220 & 2.207 & 0.100 \\
8 & Urban high-income non-agricultural labor & 0.170 & 2.363 & 0.160
\end{tabular}


among rural agricultural labor, rural agricultural entrepreneur, and low-income non-agricultural labor shows a decline. A decrease in utility is related to a decrease in household expenditure for rural agricultural labor and rural agricultural entrepreneur households.

An increase in subsidy influences poverty rate among households as depicted by head count index, poverty depth, and poverty severity. These three indicators of poverty show a decreasing trend as a result of an increase in subsidy (Table II.7). The biggest downsizing lies on poverty severity particularly among household in the rural area. This finding shows that the role of subsidy is significant in reducing poverty in Indonesia.

\begin{tabular}{|c|c|c|c|c|}
\hline \multirow{3}{*}{ No } & \multicolumn{4}{|c|}{$\begin{array}{c}\text { Tabel II.7 } \\
\text { Simulation Results of an Increase in Subsidy on the Change in Poverty (\%) }\end{array}$} \\
\hline & \multirow{2}{*}{ Household classifications } & \multicolumn{3}{|c|}{ \% Change } \\
\hline & & $\alpha=0$ & $\alpha=1$ & $\alpha=2$ \\
\hline 1 & Rural agricultural labor & -2.131 & -3.074 & -3.547 \\
\hline 2 & Rural agricultural entrepreneur & -3.463 & -4.672 & -5.372 \\
\hline 3 & Rural low-income non-agricultural labor & -2.967 & -4.664 & -5.507 \\
\hline 4 & Rural non-labor force and undefined group & -3.047 & -4.584 & -5.408 \\
\hline 5 & Rural high-income non-agricultural labor & -3.856 & -5.033 & -6.000 \\
\hline 6 & Urban low-income non-agricultural labor & -4.138 & -6.068 & -6.627 \\
\hline 7 & Urban non-labor force and undefined group & -5.641 & -5.922 & -6.330 \\
\hline 8 & Urban high-income non-agricultural labor & -5.778 & -6.235 & -6.784 \\
\hline
\end{tabular}

\section{IV.4. The Impact of Income Transfer Policy on Indonesia Economic Performance}

This section describes the simulation results of government policy to increase transfer of income by 10 percent on sectoral economic performance. Transfer of income is the allocation of government expenditure for poor household. The impact of that income transfer to sectoral economic performance, and income and poverty among household are described below.

\section{IV.4.1. The Impact of Income Transfer on Sectoral Economic Performance}

An increase in income transfer amounting Rp. 100000 to household has an impact on output, output price, and labor absorbtion rate. The results of this simulation are presented in Table II.8. It is shown that an increase in transfer of income to household has a positive impact on the output of several sectors - agriculture; public utility (electricity, gas, and water); transportation and telecommunication; and finance, leasing, and business service. However mining and quarrying; manufacturing industry; and trade, hotel, and restaurants sectors show a negative impact as a result of an increase in transfer of income to household. Transfer of 
income also has a negative impact on output price for mining and quarrying; manufacturing industry; and construction sectors. An increase in the transfer of income has a positive impact on labor absortion rate of several sectors - agriculture (0.069\%); provison of public utility (0.209\%); transportation and communications (0.034); and finance, leasing, and business service $(0.004 \%)$. The rest of the sectors either show a negative job creation or stagnant demand for labor. The trend in job creation for various sectors follows the demand for labor in terms of the sign of the coefficients.

\begin{tabular}{l|c|c|c|}
\multicolumn{4}{c}{ Tabel II.8 } \\
\multicolumn{3}{|c|}{ Simulation Results of Income Transfer on Sectoral Economic Performance (\%) } \\
\hline \multicolumn{1}{|c|}{ Sector } & Output & Price & Labor \\
\hline Agriculture & 0.055 & 0.017 & 0.069 \\
Mining and Quarrying & -0.002 & -0.005 & -0.008 \\
Manufacturing Industry & -0.026 & -0.010 & -0.056 \\
Electricity, Gas, and Clean Water & 0.063 & 0.069 & 0.209 \\
Construction & 0.000 & -0.003 & 0.000 \\
Trade, Hotel, and Restaurants & -0.028 & 0.000 & -0.035 \\
Transportation and Communications & 0.018 & 0.009 & 0.034 \\
Finance, leasing, and Business Service & 0.002 & 0.005 & 0.004 \\
Other Service & 0.000 & 0.001 & 0.000 \\
\end{tabular}

\section{IV.4.2. The Impact of Income Transfer Policy on Income and Poverty}

The simulation results of income transfer from the government to household show a significant increase in utility, income, and expenditure among rural households as shown in Table II.9. An increase in real income among rural households increases their purchasing power and expenditure and thus their level of utility. However, the impact of an increse in transfer of

\section{Tabel II.9}

Simulation Results of Income Transfer Policy on Household Utility and Income (\%)

\begin{tabular}{|c|c|c|c|c|}
\hline No & Household classifications & Utility & Income & Expenditure \\
\hline 1 & Rural agricultural labor & 2.045 & 2.624 & 1.177 \\
\hline 2 & Rural agricultural entrepreneur & 1.501 & 2.862 & 1.314 \\
\hline 3 & Rural low-income non-agricultural labor & 1.452 & 2.861 & 1.409 \\
\hline 4 & Rural non-labor force and undefined group & 1.280 & 2.855 & 1.385 \\
\hline 5 & Rural high-income non-agricultural labor & 2.670 & 4.431 & 2.847 \\
\hline 6 & Urban low-income non-agricultural labor & -1.804 & -0.186 & -1.615 \\
\hline 7 & Urban non-labor force and undefined group & -1.899 & -0.227 & -1.683 \\
\hline 8 & Urban high-income non-agricultural labor & -1.934 & -0.249 & -1.769 \\
\hline
\end{tabular}




\begin{tabular}{|c|c|c|c|c|}
\hline \multirow{3}{*}{ No } & \multirow{3}{*}{ Household classifications } & $\begin{array}{l}\text { l.10 } \\
\text { ansfer }\end{array}$ & Pove & \\
\hline & & \multicolumn{3}{|c|}{$\%$ Change } \\
\hline & & $\alpha=0$ & $\alpha=1$ & $\alpha=2$ \\
\hline 1 & Rural agricultural labor & -4.385 & -5.747 & -6.608 \\
\hline 2 & Rural agricultural entrepreneur & -4.850 & -6.539 & -7.499 \\
\hline 3 & Rural low-income non-agricultural labor & -3.804 & -5.953 & -7.012 \\
\hline 4 & Rural non-labor force and undefined group & -4.037 & -6.022 & -7.088 \\
\hline 5 & Rural high-income non-agricultural labor & -3.933 & -5.157 & -6.147 \\
\hline 6 & Urban low-income non-agricultural labor & 0.571 & 0.505 & 0.557 \\
\hline 7 & Urban non-labor force and undefined group & 0.488 & 0.635 & 0.681 \\
\hline 8 & Urban high-income non-agricultural labor & 1.000 & 0.688 & 0.749 \\
\hline
\end{tabular}

income on utility, income, and expenditure among urban households shows a decremental effect. Table II.10 shows the simulation results of an increase in tranfer of payment to household on poverty. It is found that an increase in transfer of income has reduced poverty incidence among rural households.

The objective of income transfer from the government to household is to reduce the number of poor people so that these people have access to basic needs. By undertaking this policy, the government expects that the income for each household will increase and the number of citizen that live below poverty line will decrease.

The policy of income transfer directly decreasing poverty rate particularly in rural area, as can be seen from an decreasing trend of poverty indicators such as head count index, poverty depth, and poverty severity except for urban household. This is a proof that income transfer has no strong influence to becoming a policy instrument in elevating regional economic performance.

\section{IV.5. The Impact of Fiscal Contraction and Expansion Policy on Income Distribution}

Beta density distribution function or also known as beta distribution function is used in order to examine the impact of human resource investment and income transfer on income distribution and poverty rate. The approach that is used in this research follows the suggestion of Decaluwe, et al. (1999), Cockburn (1999), and Agenor, et al. (2003), where they believe that their approach is more logical than other distribution measures. This study employs the Foster, Greer and Thorbecke (F-G-T) Indeks as a measure for poverty rate. This methods relatively more popular in poverty studies. 
Table II.11 reveals the distribution of household by income group. The variation of minimum income ranges from Rp. 44,540 to Rp. 114,260 per month, where the lowest minimum income (Rp. 35,240) is for those in the category of non-labor and undefined group in the rural area. The variation of average income ranges from Rp. 543,840 (for rural agricultural labor) to Rp. 1,028,150 (high income non-agricultural household in urban area).

\begin{tabular}{|c|c|c|c|c|c|c|}
\hline \multirow[b]{2}{*}{ No } & \multicolumn{6}{|c|}{ Tabel II.11 } \\
\hline & Household & $\begin{array}{c}\text { Mean } \\
(\operatorname{Rp} 000)\end{array}$ & $\begin{array}{c}\text { Minimum } \\
(\operatorname{Rp} 000)\end{array}$ & $\begin{array}{l}\text { Maximum } \\
(\operatorname{Rp} 000)\end{array}$ & $\begin{array}{l}\text { People } \\
\text { (Rp 000) }\end{array}$ & $\begin{array}{c}\text { Below Poverty } \\
\text { Line (\%) }\end{array}$ \\
\hline 1 & Rural agricultural labor & 543.84 & 44.54 & 999.91 & 2.88 & 57.23 \\
\hline 2 & Rural agricultural entrepreneur & 555.13 & 58.54 & 1000.00 & 23.99 & 55.07 \\
\hline 3 & Rural low-income non-agricultural labor & 559.91 & 47.14 & 6543.52 & 8.48 & 62.52 \\
\hline 4 & Rural non-labor and undefined group & 565.32 & 35.24 & 6935.20 & 29.64 & 61.35 \\
\hline 5 & Rural high-income non-agricultural labor & 560.28 & 68.15 & 4175.76 & 2.87 & 61.33 \\
\hline 6 & Urban low-income non-agricultural labor & 1001.79 & 102.16 & 8878.63 & 6.99 & 27.35 \\
\hline 7 & Urban non-labor and undefined group & 984.43 & 100.49 & 8994.67 & 22.80 & 26.98 \\
\hline 8 & Urban high-income non-agricultural labor & 1028.15 & 114.26 & 9613.13 & 2.34 & 26.13 \\
\hline
\end{tabular}

Source: Susenas, 2002

It is found that 29.64 percent of the population is under the category of non-labor and undefined group in rural area and 61.35 percent of this household lives below poverty line. This is followed by rural agricultural entrepreneur that accounted for 23.99 percent of the population and 55.07 percent of them is under poverty line. On the overall, majority of the rural people lives below poverty line. The urban poor is accounted for 26 percent of the population.

In order to analyze and evaluate income distribution based on household groups, beta density distribution function or beta distribution function is used for each household group and their respective income group. Parameter $p$ and $q$ are determined by the equation. These parameters influance income distribution disparity for respective household income group. As previously explained, when $p>q$ then the income distribution is relatively tend to be on the left side, which indicates that the inequality on income distribution increases. The same indication applies when $q>p$. If parameter $p=q$, then the function becomes symetric and income is equally distributed.

Table II.12 displays the parameter required by beta density distribution function for respective household group. Parameter $m x, m n, p$ and $q$ are estimated using the data retrieved from the Nasional Economic Social Survey (SUSENAS) in 2002. The forms of income distribution for respective household group are as shown in Figures 3 - 10. 
Tabel II.12

Parameter Values of Beta Density Distribution Function

\begin{tabular}{l|l|r|r|r|r} 
No & \multicolumn{1}{|c|}{ Households } & $\boldsymbol{p}$ & $\boldsymbol{q}$ & $\begin{array}{c}\text { Minimum (mx) } \\
\text { (Rp 000) }\end{array}$ & $\begin{array}{c}\text { Maximum (mn) } \\
\text { (Rp 000) }\end{array}$ \\
\hline 1 & Rural agricultural labor & 2.18 & 1.99 & 44.54 & 999.91 \\
2 & Rural agricultural entrepreneur & 2.16 & 1.94 & 58.54 & 1000.00 \\
3 & Rural low-income non-agricultural labor & 2.27 & 26.54 & 47.14 & 6543.52 \\
4 & Rural non-labor force and undefined group & 2.30 & 36.03 & 35.24 & 6935.20 \\
5 & Rural high-income non-agricultural labor & 2.29 & 16.14 & 68.15 & 4175.76 \\
6 & Urban low-income non-agricultural labor & 1.23 & 9.00 & 102.16 & 8878.63 \\
7 & Urban non-labor force and undefined group & 1.25 & 12.02 & 100.49 & 8994.67 \\
8 & Urban high-income non-agricultural labor & 1.16 & 10.25 & 114.26 & 9613.13
\end{tabular}

Source: Susenas, 2002

Figures 1 and 2 show income distributions for rural agricultural and rural agricultural entrepreneur households, respectively. It can be seen that the income distributions for these two groups of household are skewed to the left. Thsese findings indicate that for these two household groups the income distributions are imbalance in which there are so many low income households. In other words, for these groups of household segment, the income inequality is relatively low. This is proven by SUSENAS 2002 that the total of individual in respective household groups of rural agricultural labor and rural agricultural entrepreneur living below poverty line is relatively high, which is $\mathbf{5 7 . 2 3}$ percent and 55.07 percent, respectively. Other household groups (as depicted in Figures 5 - 10) have income distributions that are skewed to the right. These findings show that there are many individuals in these household groups have relatively high income. This situation also shows that income distribution is getting higher. This income distribution can be used to evaluate income distribution in each household group. If average income increases amounting $y$, then income in respective household in the group will also increase amounting y. Based on this argument, income distribution will move horizontally as income in respective household group changes.

Figure 3 is the simulation result for rural agricultural labor group in which an increasing in tax impacted on the increasing of inequality in income distribution, although it is relatively small. This is depicted by the proportional of beta distribution function which is moved horizontally from the left hand side to the lower part of the right hand side of poverty line. In other words, income distribution in household group of rural agricultural labor becomes more equal.

The same impact applies for household group of rural agricultural entrepreneur which is depicted in Figure 4. the subsidy and income transfer redue the income distribution inequality, associated with the shifting of the curve moves horizontally from left to right below poverty 
line. On the other hand, an increase in tax has an impact on higher income distribution inequality. However, the impacts of an increase in tax, subsidy, and transfer of income to other household groups are relatively insignificant to the changes in income distribution.

\section{SUMMARY}

In summary, the simulation results show that, firstly, in agregate an increase in non-direct tax and transfer of income to rural household has a negative impact on macro-economic performance. Secondly, an increase in non-direct tax has mixed impacts on various sectors and household groups. Manufacturing industry; and trade, hotel, and restaurants sectors have a negative impact from an increase in non-direct tax. Generally, output price in every sector shows an increasing trend. The secondary and tertiary sectors experience a higher in price compared to those in the primary sector.

It is found that household utility among rural agricultural labor and entrepreneur has increased as a result of an increase in non-direct tax. However, other household groups show a decrease in utility. This is impacting on the increasing number of head count index or poverty incidence, poverty depth index and poverty severity index in respective household groups. The highest increasing index in respective household groups is poverty severity index. This is followed by poverty depth index and head count index.

Thirdly, an increase in subsidy resulting in the declining in price for mining and quarrying; manufacturing; and electricity, gas, and water sectors. The impact of an increase in subsidy on poverty shows a significant decreases, particularly in rural area.

Fourthly, the impact of an increase in transfer of income to the rural household shows a mixed reults on output, output price, and labor demand. An increase in income increases output demand. Since the demand for input labor is a derived demand, thus there is an increase in the demand for labor. Transfer of income from the government to rural household positively influences household utility, income, and expenditure. However, it is found that the level of utility, real income, and expenditure among urban household have decreased. Income transfer policy directly decreases poverty rate particularly in rural area. It can be seen by looking at all poverty indicators such as head count index, poverty depth and poverty severity which has increased, except for urban household. 


\section{REFFERENCES}

Atkinson, A.B. and J.E. Stiglizt. (1976). The Structure of Indirect Taxation and Economic efficiency. Journal of Public economics, 1:97-119.

Basri, Faisal. (2002). Perekonomian Indonesia: Tantangan dan Harapan Bagi Kebangkitan Ekonomi Indonesia, Jakarta: Erlangga.

Cockburn, J. (2001). Trade Liberalization and Poverty in Nepal: A Computable General Equilibrium Microsimilation Analysis. Centre for Study of African economies/CSAE, Nuffield College (Oxford University) and CREFA, Canada: Universite Laval. Quebec.

Damuri, Yose Rizal and Ari A. Perdana. (2003). The Impact of Fiscal Policy on Income distribution and Poverty: A Computable General Equilibrium Approach for Indonesia. Economic Working Paper Series. Jakarta: Centre For Strategic and International Studies.

Darsono. (2008). Analisis Keefektifan Kebijakan Fiskal Terhadap Kinerja Sektor Pertanian Dengan Penekanan Pada Agroindustri di Indonesia. Disertasi Doktor (tidak dipublikasikan). Bogor: Sekolah Pascasarjana Institut Pertanian.

Decaluwé, B., A. Patry, L. Savard., and E. Thorbecke, (1999). Poverty Analysis Within a General Equilibrium Framework. Working Paper 99-06. CRÉFA, Département d'économique Université Laval.

Decaluwé, B., A. Patry and L. Savard, (1998). Income Distribution, Poverty Measures and Trade Shocks: A Computable General Equilibrium Model of a Archetype Developing Country. Département d'économique. Université Laval.

Decaluwé, B., J.-C. Dumont and L. Savard. (1999). Measuring Poverty and Inequality in a Computable General Equilibrium Model", Working paper 99-20, CREFA, Université Laval Departemen Keuangan RI. 2009. Kerangka Ekonomi Makro dan Pokok-Pokok Kebijakan Fiskal

Tahun 2010. Paparan Menteri Keuangan pada Rapat Kerja Panitia Anggaran DPR RI 1 Juni 2009.

Dervis, K, J. de Melo and S Robinson. 1982. General Equilibrium Models for Development Policy. Cambridge University Press, London, pp.1-526.

Handoko, Rudi dan Patriadi, Pandu. (2005). Evaluasi Kebijakan Subsidi NonBBM. Kajian Ekonomi dan Keuangan. Vol.9. No.4. Desember 2005.

Husain, A. and A. Chowdhry. (2001). Open-Economy Macroeconomics for Developing Countries. Northampton: Edwar Elger, Cheltenham.

Hutahean, P., Purwiyanto, A. Hadiyanto, Askolani dan S.L.Rahayu. (2002). Bunga rampai Kebijakan Fiskal. Jakarta: Badan Analisis Fiskal Departemen Keuangan RI. 
James, S. and C. Nobes. (1992). The Economics of Taxation. Fourth Edition. United Kingdom: Prentice Hall International.

Mankiw, N.G. 2003. Macroeconomics. Fifth Edition. Worth Publisher, New York.

Mirrlees, J.A. (1976). An Exploration in the Theory of Optimum Income Taxation. Review of economic Studies, 38:175-208.

Myles, G.D. (1997). Public Economics. Cambridge: University Press Cambridge.

Norton, R.D. (2004). Agricultural Development Policy: Concept and Experiences. Food and Agricultural Organization and John willey and sons Ltd. West Sussex.

Ravallion, M. and B. Bidani. (1994). How Robust Is a Poverty Profile? World Bank Economic Review, vol. 8, pp 75-102.

Republik Indonesia. (2009). Nota Keuangan dan Anggaran Pendapatan dan Belanja Negara Tahun Anggaran 2010.

Romer, D. (2001). Advanced Macroeconomics. Second Edition. New York: McGraw-Hill Book Co.

Soediyono 1985. Ekonomi Makro: Analisis IS-LM dan Permintan Agregatif. Liberty. Yokyakarta. Spencer, Milton H. \& Amos, Orley M. Jr. (1993). Contemporary Economics, Edisi ke-8, Worth Publishers, New York.

Stiglitz, J.E. (2000). Economic of The Public Sector. Third edition. New York: W.W. Norton and Company.

Sukirno, S. (2005). Makroekonomi Modern: Perkembangan Pemikiran Dari Klasik Hingga Keynesian Baru. Jakarta: Rajawali Press.

Suparmoko. M. (2003). Keuangan Negara dalam Teori dan Praktik, Edisi ke-5, BPFE, Yogyakarta. Turnovsky, S.J. 1981. Macroeconomic Analysis and Stabilization Poliscy. Cambridge University Press, Cambridge. 


\section{APPENDIX}

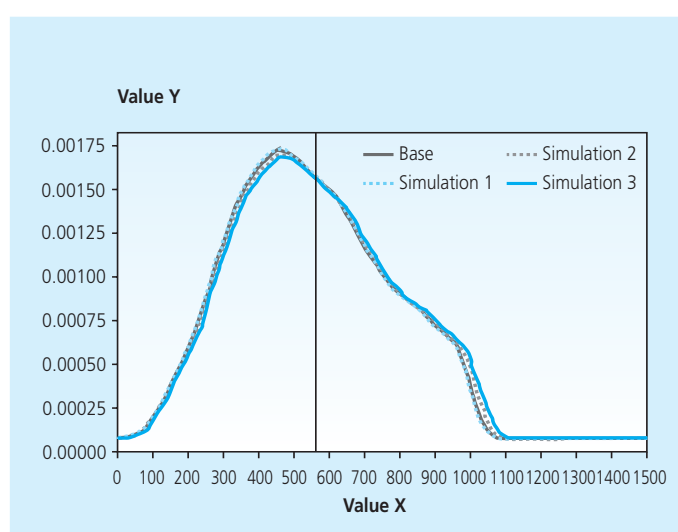

Figure 1

Income Distribution for Agricultural

Employee

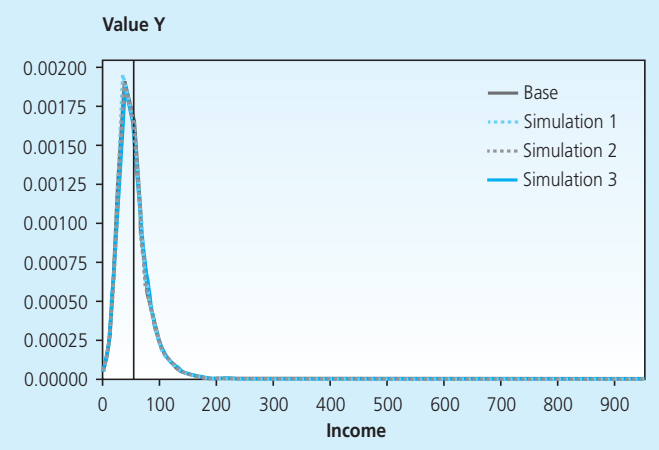

Figure 3

Income Distribution for Rural Low-Income Non-Agricultural
Value $Y$

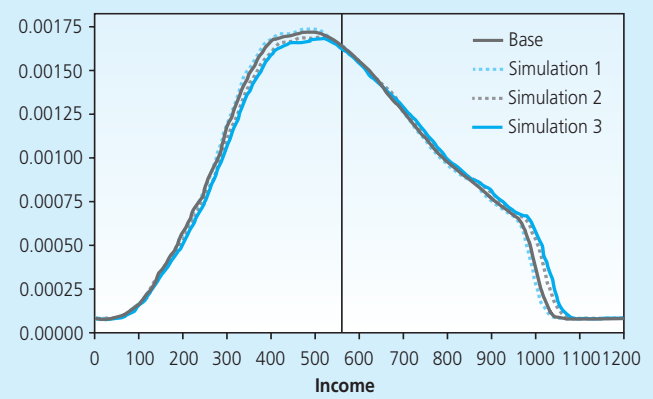

Figure 2

Income Distribution for Agricultural

Employer

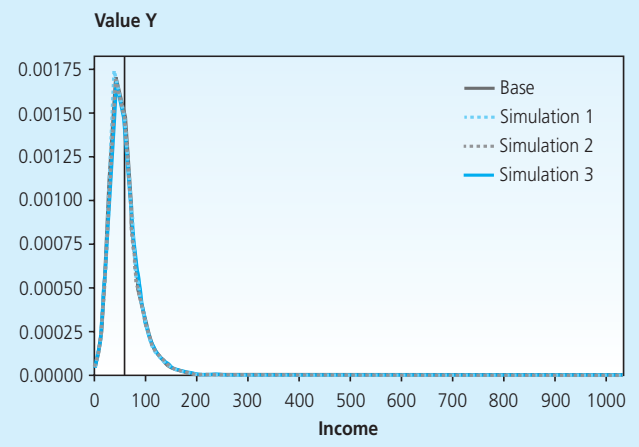

Figure 4

Income Distribution for Rural Non-Labor Force and Unacounted Occupation 
Value $Y$

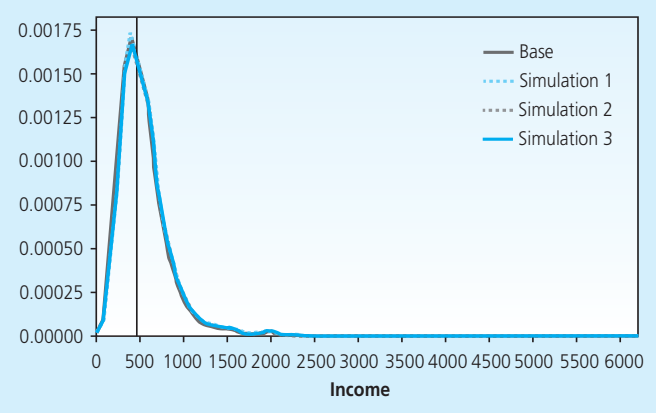

Figure 5

Income Distribution for Rural High-Income Non-Agricultural

Value $Y$

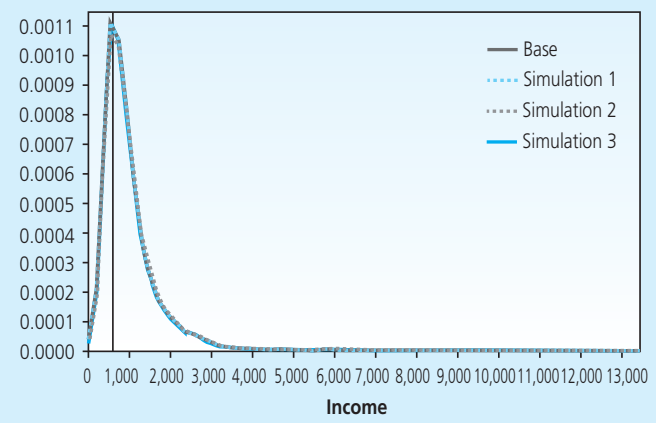

Figure 7

Income Distribution for Urban Non-Labor Force and unacounted Occupation
Value $Y$

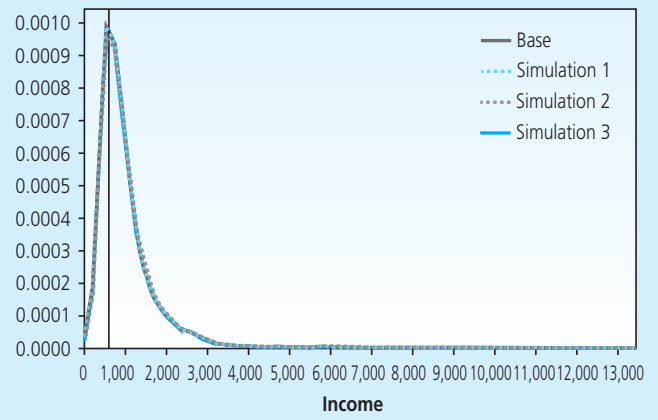

Figure 6

Income Distribution for Urban Low-Income Non-Agricultural

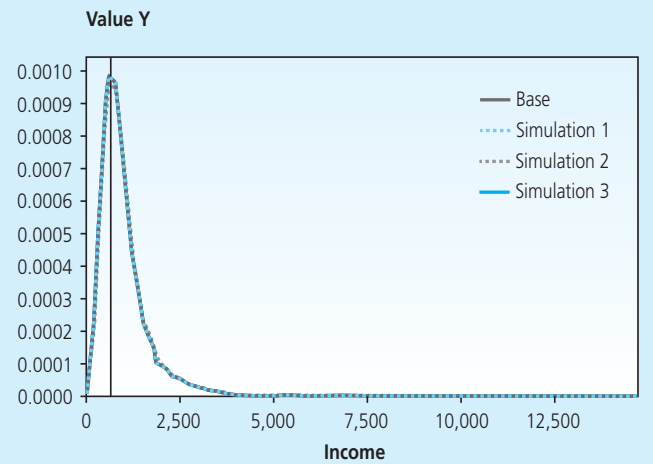

Figure 8

Income Distribution for Urban High-Income Non-Agricultural 